\title{
Comparison of traditional and automated nursing records in the medicine services of the Callejón de Huaylas hospitals - Peru [Comparación de los registros de enfermería tradicionales y automatizados en los servicios de medicina de los hospitales del Callejón de Huaylas - Perú]
}

\author{
Llermé Núñez Zarazúa,* (D), Bibiana León Huerta ${ }^{a}$ (D), Olga Giovanna Valderrama- \\ Ríos $^{b}$ (i) \\ aFacultad de Ciencias Médicas. Escuela Profesional de Enfermería. Universidad Nacional \\ Santiago Antúnez de Mayolo, Perú. \\ ${ }^{b}$ Facultad de Ciencias de la Salud. Escuela Profesional de Enfermería. Universidad Nacional del \\ Callao-Perú. Av. Juan Pablo II 306 Bellavista Callao, Peru. \\ *opebri@yahoo.com
}

Received: 26 January 2021; Accepted: 26 February 2021; Published: 1 March 2021

\section{Resumen}

El objetivo del presente estudio fue comparar la calidad de los registros de enfermería tradicionales y automatizados, en los servicios de medicina de cuatro hospitales del Callejón de Huaylas - Perú. Investigación de enfoque cuantitativo, cuasi experimental. La población estuvo conformada por 32,940 registros de enfermería de las historias clínicas y la muestra fue de 816 registros, seleccionados mediante muestreo probabilístico estratificado. Los instrumentos utilizados fueron; inventario de calidad del registro de enfermería y el software denominado Sistema Automatizado de Registro de Enfermería (SIARE) versión 1.0. Los resultados muestran que la diferencia de calidad de los registros de enfermería tradicionales y automatizados, con la prueba t de student obtuvieron una media de 7,284 , una DS de 1,172 , un valor $\mathrm{t}=29,815$, con g.l. 22 y un valor $p=0,000$, resultando diferencias significativas entre los puntajes de calidad de los registros tradicionales y automatizados de enfermería de los servicios de medicina de los hospitales del callejón de Huaylas. Se concluye que la calidad (estructura, continuidad del cuidado y seguridad del paciente) de los registros automatizados es alta en comparación con los registros tradicionales de enfermería.

Palabras clave: Registros, enfermería, calidad, software, automatización.

\begin{abstract}
The objective of this study was to compare the quality of traditional and automated nursing records in the medical services of four hospitals in Callejón de Huaylas - Peru. Investigation of quantitative approach quasi experimental. The population consisted of 32,940 nursing records from the medical records, and the sample consisted of 816 records, selected by stratified probability sampling. The instruments used were; Quality inventory of the nursing record and the software called the Automated Nursing Record System (In Spanish SIARE) version 1.0. The results show that the difference in quality of the traditional and automated nursing records, with the student's t test obtained a mean of 7.284, a SD of 1.172 , a t value $=29.815$, with d.f. 22 and a $p$ value $=0.000$, resulting in significant differences between the quality scores of the traditional and automated nursing records of the medicine services of the hospitals of the Callejón de Huaylas. It is concluded that the quality (structure, continuity of care and patient safety) of the automated records is high in comparison with traditional nursing records.
\end{abstract}




\section{CMS: Journal of Global Health and Medicine}

Vol. 5, $\mathrm{N}^{\circ} 1,2021$
Copyright @ 2021, CINCADER.

ISSN 2523-9511

DOI: https://doi.org/10.32829/ghmj.v5i1.217
A publication of

Centre of Research and Training for

Regional Development

Online at www.journals.cincader.org

Keywords: Records, nursing, quality, software, automation.

\section{Introduction}

The technical norm of quality standards for hospitals and specialized institutes, refers that all the institutions that provide health services have the function of guaranteeing the user quality care, that is, safe, of less risk and of greater benefit to their health. satisfaction of the service provided (MINSA, 2003).

According to MINSA (2018), the medical history is a document whose content is of legal, scientific relevance, in which the processes related to the user's care are recorded, in an orderly, integrated, sequential and immediate way to care that health professionals provide to the user. The clinical history comprises a series of formats in which the nursing records are found; Its proper administration and management contribute directly to improving the quality of patient care, as well as optimizing the management of health facilities, protecting the legal interests of the patient, health personnel and the facility, as well as providing information for research and teaching purposes.

The Nursing Care Process (in Spanish PAE) is the application of scientific resolution to Nursing care, this process is used to identify patient problems, plan and carry out nursing care in a systematic way and to evaluate the results obtained with these cares (Marriner, 2011). One of the functions of the nursing professional corresponds to providing comprehensive nursing care based on the Nursing Care Process (PAE), which includes its assessment, diagnosis, planning, execution and evaluation; to later be compulsorily registered in the user's medical record (Colegio de Enfermeros del Perú, 2002).

The Nursing Care Process is the methodology of care, and in each phase of its application when providing care to the person, family and community, where a broad theoretical framework of Nursing is used that leads to providing care of scientific quality, technical and human (Bellido, 2010). There are many tools to define the elements contained in the nursing care process, highlighting the nursing diagnoses of the International NANDA (Herdman and Kamitsuru, 2018), the Nursing Outcomes Classification-NOC (Moorhead et al, 2018) and the Classification of Nursing Interventions-NIC (Bulechek et al, 2018). The standardization of language through this interrelation allows greater practice and efficiency in nursing care (Ramos et al., 2011). The establishment of care plans guarantees the quality of care and the clinical safety to patients.

Nursing records (García, 2007) are used 24 hours a day and continuously by the nursing professional, where the NANDA-NIC-NOC interrelation is expressed based on clinical judgment and knowledge about user care, Therefore, the correct administration and management of these allows to know the evolution of the patient, outstanding facts or events, as well as interventions carried out, in order to provide continuity and security in the treatment, in addition to transmitting valid and reliable information to the team. health (Ramos et al., 2011).

In the institutions that provide health services in most countries, the nursing records continue to be used in a traditional and historical manual way, the nursing professionals making the nursing notes in a descriptive way, appreciating the fragmentation of the manuscript. However, with the digital automation of records, a higher quality of care is expected in less time, using information technology to benefit patient care. On the other hand, systematized electronic nursing records (Torres and Amarilis, 2011) help to provide comprehensive nursing care and nursing professionals respond to users' demands with criteria of quality, timeliness, continuity, safety and integrity. 


\section{GMS \\ Journal of Global Health and Medicine}

Vol. 5, $\mathrm{N}^{\circ}$ 1, 2021

Copyright @ 2021, CINCADER.

ISSN 2523-9511

DOI: https://doi.org/10.32829/ghmj.v5i1.217

The structuring of the automated systems in nursing offers the advantage the ease of searching for contextualized patient information, helping the professional to make decisions, unify the nursing language, increase the quality of the record and enable the retrieval and subsequent analysis of data (Suarez, 2013).

Therefore, and there is a scientific gap in the evaluation of the quality of electronic nursing records in Peru, due to the fact that there is still no software to automate these records at the level of the institutions that provide health services; The objective of this study was to compare the quality of traditional and automated nursing records in the Medicine services of the Callejón de Huaylas hospitals.

\section{Materials and methods}

The study population consisted of 32,940 nursing records contained in the medical records of the medical services of the hospitals of Callejón de Huaylas: Huaraz, Carhuaz, Yungay and Caraz, in the Ancash-Peru region, during the year 2019. The sample was selected by stratified probability sampling, finally having 408 traditional records and 408 automated nursing records from the four hospitals.

The data obtained were processed with basic statistics. Before applying the study, a nursing registry software called the automated nursing registry system (SIARE) version 1.0 was built, based on the NANDA International taxonomy, as well as the NOC Nursing Outcomes, NIC Nursing Interventions and with SOAPIE nursing records; S-subjective data, O-objective data, DDiagnosis, P-Planning, I-Intervention and E-Nursing Assessment, for adult patients admitted to the medicine service of the four hospitals. The platform was designed to be used with a tablettype mobile device in the patient's unit, to then generate a form for the documented medical history and also be stored in the software database.

The other instrument that was applied to each unit of analysis, in two moments: before and after the use of SIARE version 1.0, was the Quality Inventory of the nursing record. This inventory consisted of 33 items, each with a score of: one 1 (present) and zero 0 (absent) in a checklist, prepared ad hoc and defined the quality of the record in: Each page of the nursing records it has the identification data of the patient. The items dealt with: general data; date of admission, date of care, progressive number of the day of hospital stay; sociocultural data of the patient (religion, language-dialect, etc.); objective data: vital signs; assessment of the patient's pain (frequency, location, duration, intensity); nursing diagnosis; nursing outcomes and interventions; in addition to; characteristics of the site of insertion of invasive media, of the wounds (pressure ulcers, postoperative, drugs administered indicating the eleven emails for their administration); use of universally or institutionally accepted units or abbreviations; applied security measures; prevention of pressure ulcers; health education; evaluation of interventions; pain evolution; pending situations of the patient and technical language, font and identification of the nurse responsible for the record. Before applying the study, the described inventory was subjected to expert judgment and reliability studies through a pilot test; obtaining a reliability of 0.837 , a construct validity by factorial analysis of $86.1 \%$ with a Kaiser Meyer Olkin (KMO) adequacy of 0.591 and a Lawshe content validity of 1 . The data were processed in the statistical program SPSS version 24.0 and analyzed with basic statistical methods.

The present investigation did not have any bioethical implication, since the units of analysis were written records of medical records; Prior to the study, administrative consents were requested from the entities where the research was carried out. 
Vol. 5, $\mathrm{N}^{\circ} 1,2021$

Copyright @ 2021, CINCADER.

ISSN 2523-9511

DOI: https://doi.org/10.32829/ghmj.v5i1.217

\section{Results}

Table 1. Quality of the Traditional and Automated Nursing Records (NR) of the Medicine services of hospitals in Callejón de Huaylas

\begin{tabular}{lcccc}
\hline & \multicolumn{2}{c}{ NR Tradicionals } & \multicolumn{2}{c}{ NR Automated } \\
\cline { 2 - 6 } \multicolumn{1}{c}{ Quality level } & $\mathrm{N}^{\circ}$ & $\%$ & $\mathrm{~N}^{\circ}$ & $\%$ \\
\hline Low & 65 & 16 & 0 & 0 \\
Low average & 192 & 47 & 0 & 0 \\
High average & 107 & 26 & 5 & 1 \\
High & 44 & 11 & 403 & 99 \\
\hline Mean & \multicolumn{2}{c}{16,8} & & \multicolumn{3}{c}{24,0} \\
Standard Deviation & \multicolumn{2}{c}{2,5} & & \\
\hline
\end{tabular}

After the data was processed, the quality of traditional and automated nursing records were compared. In traditional nursing records, $47 \%$ presented a low average level, $26 \%$ a high average level, while $11 \%$ presented a high quality level. While, in the quality of the automated nursing records, $99 \%$ presented a high level; As can be seen in Table 1. When comparing the quality of both records, the traditional records presented a mean of 16.8 with a SD of 2.5; and the automated nursing records had an average of 24.0 and a SD of 1.5. Data that agree with Morales (2012) who showed that traditional nursing notes present a significant percentage of fair quality. On the other hand, González et al. (2004), affirm that nursing records show the comprehensive care provided by the nursing professional, so it is important that they be of quality, and allow continuity of hospitalized patient care. Likewise, Aedo et al. (2012), affirm that the development of an automated nursing registration system reduces the time to register manually, being accurate and useful for professional practice. On the other hand, Heui (2018), refers that the electronic nursing record is of great help to provide better care. Likewise, (Sanguino, 2013) emphasizes that the computerized nursing record improves the quality of information for decision-making, improves comprehensive care, early detection of alerts, clinical evolution and the integrity and identity of the nursing work.

Table 2. Level of quality of the structure, continuity and security of the traditional and automated nursing records of the medical services of the Callejón de Huaylas hospitals

\begin{tabular}{lcccc}
\hline \multirow{2}{*}{ Quality level } & \multicolumn{3}{c}{ Nurising records (NR) } \\
\cline { 2 - 5 } & \multicolumn{2}{c}{ Traditionals } & \multicolumn{2}{c}{ Automated } \\
\cline { 2 - 5 } & $\mathrm{N}^{\circ}$ & $\%$ & $\mathrm{~N}^{\circ}$ & $\%$ \\
\hline STRUCTURE & 51 & 13 & 0 & 0 \\
Low & 139 & 34 & 0 & 0 \\
Low average & 151 & 37 & 35 & 9 \\
High average & 67 & 16 & 373 & 91 \\
High & & & & \\
\hline CONTINUITY & 74 & 18 & 0 & 0 \\
Low & 238 & 58 & 0 & 0 \\
Low average & 0 & 0 & 5 & 1 \\
High average & & &
\end{tabular}




\section{Journal of Global Health and Medicine}

Vol. 5, $\mathrm{N}^{\circ}$ 1, 2021
Copyright @ 2021, CINCADER.

ISSN 2523-9511

DOI: https://doi.org/10.32829/ghmj.v5i1.217

\begin{tabular}{lcccc} 
High & 96 & 24 & 403 & 99 \\
\hline SECURITY & & & & \\
Low & 86 & 21 & 0 & 0 \\
Low average & 154 & 38 & 14 & 3 \\
High average & 128 & 31 & 95 & 23 \\
High & 40 & 10 & 299 & 73 \\
\hline
\end{tabular}

Table 2 shows the quality level of the structure of traditional nursing records, $37 \%$ present a high average level; while in the automated records $91 \%$ presented a high level of quality. Regarding the quality of the continuity of patient care, in the traditional nursing registries $58 \%$ present a low average level, and in the automated registries $99 \%$ present a high level. While the quality of patient safety, it was found that $38 \%$ present a low average level in the traditional ones and $73 \%$ of the automated records present a high level of quality.

In this regard, Cajaleón (2017) reported that the quality of manual registration is mostly medium with a downward trend. In contrast, Valdez (2011) found that there was an improvement in the quality of clinical records when using electronic tools. Likewise, Simian (2019) affirms that the clinical data accumulated in health records represent an opportunity for the development of research when they are electronic.

Table 3. Test of equality of qualifications of the Quality items of the traditional and automated nursing records of the medicine service of the hospitals of Callejón de Huaylas

\begin{tabular}{ccccccccccc}
\hline & \multicolumn{1}{c}{ NR Traditionals } & \multicolumn{1}{c}{ NR Automated } & \multicolumn{2}{c}{ Wilcoxon test of signed } \\
\cline { 2 - 9 } Ítem & Present & Absent & \multicolumn{2}{c}{ Present } & \multicolumn{2}{c}{ Absent } & \multicolumn{2}{c}{ ranks } \\
\cline { 2 - 9 } & $\mathbf{n}$ & $\%$ & $\mathbf{n}$ & $\%$ & $\mathbf{n}$ & $\%$ & $\mathbf{n}$ & $\%$ & $\mathbf{Z}$ & Sig. \\
\hline 1 & 399 & 98 & 9 & 2 & 408 & 100 & 0 & 0 & 2,226 &, 026 \\
2 & 206 & 50 & 202 & 50 & 408 & 100 & 0 & 0 & 3,304 &, 001 \\
3 & 404 & 99 & 4 & 1 & 408 & 100 & 0 & 0 & 1,604 &, 109 \\
4 & 281 & 69 & 127 & 31 & 373 & 91 & 35 & 9 & 3,586 &, 000 \\
5 & 399 & 98 & 9 & 2 & 408 & 100 & 0 & 0 & 2,214 &, 027 \\
6 & 400 & 98 & 8 & 2 & 408 & 100 & 0 & 0 & 2,226 &, 026 \\
7 & 253 & 62 & 155 & 38 & 374 & 92 & 34 & 8 & 4,199 &, 000 \\
8 & 1 & 0 & 407 & 100 & 346 & 85 & 62 & 15 & 4,208 &, 000 \\
9 & 0 & 0 & 408 & 100 & 2 & 0 & 406 & 100 & 1,342 &, 180 \\
10 & 0 & 0 & 408 & 100 & 398 & 98 & 10 & 2 & 4,375 &, 000 \\
11 & 0 & 0 & 408 & 100 & 181 & 44 & 227 & 56 & 4,200 &, 000 \\
12 & 10 & 2 & 398 & 98 & 10 & 2 & 398 & 98 &, 268 &, 788 \\
13 & 397 & 97 & 11 & 3 & 399 & 98 & 9 & 2 &, 823 &, 411 \\
14 & 335 & 82 & 73 & 18 & 338 & 83 & 70 & 17 & 1,494 &, 135 \\
15 & 4 & 1 & 404 & 99 & 4 & 1 & 404 & 99 &, 736 &, 461 \\
16 & 194 & 48 & 214 & 52 & 402 & 99 & 6 & 1 & 3,742 &, 000 \\
17 & 6 & 1 & 402 & 99 & 6 & 1 & 402 & 99 &, 898 &, 369 \\
18 & 63 & 15 & 345 & 85 & 13 & 3 & 395 & 97 & 2,931 &, 003 \\
19 & 310 & 76 & 98 & 24 & 408 & 100 & 0 & 0 & 3,190 &, 001 \\
20 & 408 & 100 & 0 & 0 & 408 & 100 & 0 & 0 &, 000 & 1,000 \\
21 & 403 & 99 & 5 & 1 & 408 & 100 & 0 & 0 & 1,826 &, 068 \\
22 & 54 & 13 & 354 & 87 & 31 & 8 & 377 & 92 & 1,537 &, 124 \\
23 & 10 & 2 & 398 & 98 & 4 & 1 & 404 & 99 & 1,550 &, 121 \\
24 & 68 & 17 & 340 & 83 & 76 & 19 & 332 & 81 & 1,511 &, 131 \\
& & & & & & & & & &
\end{tabular}




\section{CMS: Journal of Global Health and Medicine}

Vol. 5, $\mathrm{N}^{\circ} 1,2021$
Copyright @ 2021, CINCADER.

ISSN 2523-9511

DOI: https://doi.org/10.32829/ghmj.v5i1.217

\begin{tabular}{ccccccccccc}
25 & 6 & 1 & 402 & 99 & 393 & 96 & 15 & 4 & 4,290 &, 000 \\
26 & 85 & 21 & 323 & 79 & 337 & 83 & 71 & 17 & 4,114 &, 000 \\
27 & 103 & 25 & 305 & 75 & 408 & 100 & 0 & 0 & 4,203 &, 000 \\
28 & 340 & 83 & 68 & 17 & 408 & 100 & 0 & 0 & 3,871 &, 000 \\
29 & 377 & 92 & 31 & 8 & 408 & 100 & 0 & 0 & 3,305 &, 001 \\
30 & 302 & 74 & 106 & 26 & 408 & 100 & 0 & 0 & 3,923 &, 000 \\
31 & 256 & 63 & 152 & 37 & 408 & 100 & 0 & 0 & 2,000 &, 046 \\
32 & 391 & 96 & 17 & 4 & 408 & 100 & 0 & 0 & 3,089 &, 002 \\
33 & 391 & 9 & 17 & 4 & 408 & 100 & 0 & 0 & 2,859 &, 004 \\
\hline
\end{tabular}

According to the quality dimensions of the nursing records, in relation to the structure, it was observed that the traditional nursing record presented a fulfillment of 9 items, the result of the automated nursing record a fulfillment of 11 items. Regarding the continuity of care, it was observed that, on average, the traditional nursing records had a compliance of 4 items, while in the automated records, there was a compliance of 7 items. For the quality of patient safety, the average of the traditional nursing record presented a compliance of 4 items, while in the automated one, a compliance of 6 items.

The variation suffered by the items in the nursing records before and after the experiment was also observed after applying the Wilcoxon equal scores test for the signed ranges. Thus, it was observed that 23 items (70\%) improved in their scores or compliance after the experiment, leaving only ten items without significant variation.

To determine the difference in the quality of the traditional and automated nursing records, after verifying the normality of the sample, the student's $t$ test was applied for paired related samples, finding a mean of 7.284 , a SD of 1.172, a value $t=29.815$, with d.f. 22 and a $p$-value $=0.000$; This indicates that there are significant differences between the quality scores of the traditional and automated nursing records of the medicine service of the four hospitals in Callejón de Huaylas.

\section{Conclusions}

To determine the difference in the quality of the traditional and automated nursing records, there are significant differences between the quality scores of the traditional and automated nursing records of the medicine service of the Callejón de Huaylas hospitals, which is why its application is recommended in these health institutions.

\section{References}

Aedo V, Parada T, Alcayaga C, R. M. Registro electrónico de enfermería en la valoración de las heridas. Enfermeria Global, 2012, 28, 386-395.

Armengol M, Mestres O, Molina T, Puertas N, Artal M, C. S. Experiencia en la Implantación del aplicativo informático Gacela Care en la Unidad de Neurocirugia del Hospital Vall D’Hebron de Barcelona. 2011. 1, 4-7. https://www.neurotrauma.net/

Bellido Vallejo J, L. C. J. Proceso Enfermero desde el modelo de cuidados de Virginia Henderson y los Lenguajes NNN. 1st ed. 2010.

Bulechek, G. M., Butcher, H. K., Dochterman, J.M., Wagner, C. M. Clasificación de Intervenciones de Enfermería (NIC). 7th ed. 2018. 
Vol. 5, $\mathrm{N}^{\circ} 1,2021$

Copyright @ 2021, CINCADER.

ISSN 2523-9511

DOI: https://doi.org/10.32829/ghmj.v5i1.217

Cajaleón Chávez L. Calidad del registro de enfermería en el servicio hospitalización de Medicina Il del Hospital Alberto Sabogal. Tesis Maestria., 2017, 1-92.

Colegio de Enfermeros del Perú. Ley del Trabajo de la Enfermera. Colegio de Enfermeros del Perú, 2002, 30. http://www.conaren.org.pe

García S, Navío A, V. L. Normas básicas para la elaboración de los registros de enfermería. Nure Investigación, 2007, 28, 1-8.

González Sánchez J, Cosgaya Garcia O, Simón Garcia M, B. M. A. Registros de enfermería: convencional frente a informatizado. Unidad de cuidados críticos. Enfrm Intensiva, 2004, 15(2), 53-62.

Herdman H. Kamitsuru, Sh. NANDA Internacional. Diagnósticos enfermero. Definiciones y clasificación 2018-2020. 2019, 11th ed.

Heui S, S. Y. Changes in nursing professions scope of practice: A pilot study using electronic nursing records. Health Policy and Technology, 2018, 7(1), 15-22. https://doi.org/10.1016/j.hlpt.2017.12.003

Marriner T. Modelos y teorías en Enfermería. 7th ed. Elsevier, 2011.

MINSA. Normas Técnicas de estándares de Calidad para Hospitales e Institutos Especializados. Setiembre, 2003, 68. https://www.minsa.gob.pe

MINSA. Norma técnica de salud para la gestión de la historia clínica. 2018. Pág. 28-32.

Moorhead S, Johnson M, Maas, S. E. Clasificación de Resultados de Enfermería (NOC) Medición de Resultados en Salud. 6th ed. 2018.

Morales Loayza S. Calidad de las notas de Enfermería en la Unidad de Cuidados Intensivos. $2012,122$.

Pérez, J. M. C., \& Palacios-ce, C. Á. D. El significado del lenguaje estandarizado NANDA-NICNOC en las enfermeras de cuidados intensivos madrileñas: abordaje fenomenológico. Enferm Intensiva, 2012, 23(2), 68-76. https://doi.org/10.1016/j.enfi.2011.12.001

Ramos-silva, E., Guadalupe, M., San-juan, D. Conocimiento y percepciones de la adecuada cumplimentación de los registros de enfermería en un centro de tercer nivel. Enferm Clin., 2011, 21(3), 151-158. https://doi.org/10.1016/j.enfcli.2011.01.008

Sanguino Rojas, J. Á. Registro de Enfermería Informatizado: Desarrollo y Conflicto de intereses en América Latina y El Caribe. Computerized Nursing Registry: Development and Conflict of interest in Latin America and the Caribbean. 2013. http://www.informatica2013.sld.cu/index.php/informaticasalud/2013/paper/viewFile/416/1

Simian D, M.-J. M. Experience in the development of research health registries. Rev. Med. Clin. Condes., 2019, 30(1), 76-82.

Suárez M. Registros de Enfermería como Evidencia del Cuidado. 2013. 1(2), 126-133.

Torres M, Amarilis R, M. R. Calidad de los registros clínicos de enfermería: Elaboración de un instrumento para su evaluación. ENEO-UNAM, 2011, 8(1), 17-25.

Valdez D. Herramientas de seguridad para el paciente: Experiencia en la implementación del expediente clínico electrónico. 2011, 33(3), 146-150. 